Doi: HTTPS://DOI.ORG/10.23910/IJBSM/2018.9.1.1858

\title{
Preference Towards Online Mode of Distance Education Courses-conjoint Analysis
}

\author{
M. Malarkodi, V. M. Indumathi and S. Praveena
}

Dept. of ARM, Tamil Nadu Agricultural University, Coimbatore (641 003), India

\section{Corresponding Author}

M. Malarkodi

e-mail: malardeepshik@gmail.com
Article History

Article ID: AR1858

Received in $19^{\text {th }}$ January, 2018

Received in revised form $28^{\text {th }}$ January, 2018

Accepted in final form 06 ${ }^{\text {th }}$ February, 2018

\begin{abstract}
In India online education was in its primitive stage. Though, maximum educational institutes had adopted the process of online admission and online result announcement, but the method of teaching through online was relatively slow in India. It was important for the universities to understand the preference towards online learning. Conjoint analysis was used to frame the preferences of sample respondents on the design of online mode of distance education. Conjoint analysis was utilized to know about the preference status among the distance learning courses offered by Tamil Nadu Agricultural university, the sample size consists of 90 Agri student and 90 non Agri student respondents. Course, Period, Format, and Duration attributes were selected for the experiment. From the results it was observed that the respondents preferred to do a certificate courses in PDF and Video format with 2 hrs of time duration for the period of one month. Majority of the agricultural students preferred PG degree courses whereas the non-agricultural students preferred certificate courses. Both agricultural and non-agricultural students preferred to do the computer related tasks. Among all the respondents, flexibility of study location was the major reason for the students to prefer online education followed by flexibility of study time and less need to go to campus. It was observed that respondents were not sure about the problems in distance education.
\end{abstract}

Keywords: Conjoint analysis, distance education, preference, online learning

\section{Introduction}

Distance education in India had a history of nearly three decades. Persistent efforts had been made by both government and voluntary organizations to achieve universal literacy and expand opportunities for female education.

In 1970, the Ministry of Education and Social Welfare in collaboration with the Ministry of Information and Broadcasting, the university grants commission and the Indian National commission for cooperation with UNESCO organized a seminar on the open University which recommended for establishment of the open university on an experimental basis. A committee was appointed by Government of India. The union education minister formed a working group under the chairmanship of Shri.G.Parthasarathi who had recommended for considering the establishment of an Open University in the country in 1971. In India, there are numerous universities like Indira Gandhi Open University, Annamalai University, IMT Jodhpur offering online courses in distance mode.

Today, distance education is offered through a variety of formats. Radio, television, telecommunications, and especially the Internet have come to play an integral role in expanding the minds of students around the world. With the wide distribution and accessibility of computers, distance learning has become faster and more prevalent. Some solely online universities such as Phoenix University have hundreds of thousands of students and numerous institutions both small and large have sprung up in the past decade. Of course, traditional universities are not without online options as well, as it is estimated that almost $96 \%$ of them offer some kind of online coursework and that millions of students across the nation are enrolled.

The Agricultural College established during 1906 celebrated its centenary year during 2005. In commemoration of the centenary year of the Agricultural College and Research Institute Coimbatore the function of TNAU viz teaching, research and extension had been enlarged with additional function of Open and Distance Learning which was first of its kind in India, among State Agricultural Universities. The Directorate of Open and Distance Learning, one of the constituent units of the TNAU was started during April, 2005 by renaming the Directorate of Publications. This Directorate has started offering certificate courses through Distance Learning Mode for those aspiring for self employment. The primary purpose of this objective was to examine the learning style, preferred source of internet utilization, preferred 
courses and preference for seeking online mode of distance education etc., Reviews related to the study are collected and are presented below.

Raut and Sharma (2009) found that the respondents were interested to join need based courses in agriculture through distance learning to enhance their knowledge and skills in the field of agriculture. They observed that it could be helpful in introducing agriculture education through State Open University in Uttarakhand.

Shaik et al. (2010) identified that majority of the respondents are willing to spend 30 minutes $-1 \mathrm{hr}$ per week for updating their knowledge, there is a possibility of introducing the e-learning strategies in extension systems. In the absence of regular training and capacity building exercises, the information disequilibrium between the extension officers and the farmers will not contribute to the favourable impacts. The study proved that one way of providing the regular information and training support $24 \times 7$ at their place of work and at their convenience is by adopting e-learning strategies.

Dahiya (2012) observed that Common template for e-Lesson development is very helpful for the faculty and students, as it gives the complete format and instructions to be followed by the teacher and it doesn't complicate the system for students by adopting different representation schemes for the lessons, Quiz, Glossary and presentations. The system is being extensively used by the students and faculty members

Soujanya et al. (2013) conducted a study on empowering rural women through distance learning and observed that there was significant impact of distance education on gain in knowledge of rural school dropout girls and women about nutrients. They stated that distance education has proved to be a very effective mode of education to empower the people who do not have access to education through formal education system

Yu et al. (2013) rated the effectiveness of online collaborative learning of Nursing students at Taiwan and found that the rating was high. The impact of students' computer skills and their ability to use the required media needs additional examination. They suggested that the need for prerequisite skills and competence in using the course management software prior to taking an online collaborative class should be studied.

Alrashidi (2014) stated that Distance education and E-learning is quickly becoming a major trend in educational delivery methods because of technological advancements. Many third world countries have explored this method as a means to educate their growing youthful populations. E-learning is very affordable, and saves the time of all involved stakeholder groups (educators, students and corporations). But need prepared training teachers with connection of electricity, internet and computers.

Balamurugan (2015) conducted a study on learning experience of small farmers in sugarcane cultivation and found that small farmers possessed low level of learning experience. They suggested that extension educational programmes such as trainings, discussion meetings, demonstration and field visit etc., for perceptual changes among the sugarcane cultivators should be encouraged.

Pooja and Ansari (2015) conducted a study on perception towards e-learning and observed that majority of students (91\%) have positive perceptions about e-Learning. The student's academic performance, computer/Laptop ownership, computer proficiency and frequency of computer use were found to have positive and significant correlation with students' perception towards e-learning.

Jayakumar et al. (2016) conducted a study on understanding the learning style of undergraduate students and revealed that majority of the students are visual learners, followed by auditory learners. They also found that the streamwise distribution of the students showed that the highest percentage of visual learners was found in engineering stream. A majority of the students were auditory learners in the horticultural and agricultural streams with 62.50 percent and $61.11 \%$ respectively.

Shaikh (2017) conducted a study on awareness to MOOCs which was divided into 3 parts-use of computers, use of Internet and awareness to MOOCs and it was found that student teachers were using You tube videos, online messaging tools such as email, blogging and Whatsapp groups, to learn things and clarify concepts. Use of Internet and online discussion tool for educational purpose was found to be very good among the student teachers. The study showed that the awareness of MOOCs is very low among the student teachers. The perceptions to MOOCs were mostly negative.

\section{Materials and Methods}

The study was conducted in Coimbatore city to check whether people were aware of the distance education programs offered by Tamil Nadu Agricultural University in various disciplines of agriculture and to assess the preference and acceptance of online courses in the same disciplines, if provided. Considering the objectives of the study, sample respondents were categorized into two groups i.e., Agricultural students and non agricultural students. From the vast number of colleges in Coimbatore, three arts colleges were selected conveniently for sampling the non agricultural students and the Tamil Nadu Agricultural University was selected for sampling the agricultural students. The sample of 90 agricultural students and 90 non agricultural students were selected based on their willingness to participate in the survey. Thus, the total sample size was 180 students.

The conjoint analysis was used to frame the preferences of sample respondents on the design of online mode of distance education. There were two major steps in designing a conjoint analysis study (1) identifying relevant attributes and possible 
values of attribute, and (2) designing the conjoint experiment.

\subsection{Identifying relevant attributes - a personal interview}

The identification of the relevant attributes and attribute levels was an important stage in the conjoint study. Common methods for deriving the list of relevant attributes - also known as 'factors' - in conjoint studies include personal interviews, expert judgment, group interviews, or computerized methods. The personal interview method was selected to identify the relevant attributes and attribute level.

Conjoint analysis had been widely used in examining preference for a wide range of attributes. In this research, the conjoint analysis did not include a large number of attributes because the respondents might find it difficult to evaluate many attributes at a time. A large number of attributes would also increase the number of possible hypothetical profiles, which might confuse the respondents. Taking into accounts academic experts and published literatures in reputed journals only four important attributes (Course, Period, Format, and Duration) were selected for the experiment. These attributes formed 16 hypothetical profiles. The attributes and attribute levels are given in the Table 1.

To test the correlation among the attributes, Pearson correlation coefficient and Kendall-tau was calculated. It was considered a strong correlation if the correlation coefficient was greater than 0.8 and a weak correlation if the correlation coefficient was less than 0.5 .

\begin{tabular}{|c|c|c|}
\hline SI. No. & Attributes & Attribute levels \\
\hline 1. & Course & $\begin{array}{l}\text { a. Degree } \\
\text { b. Certificate }\end{array}$ \\
\hline 2. & Period & $\begin{array}{l}\text { a. } 6 \text { months } \\
\text { b. } 3 \text { months } \\
\text { c. } 1 \text { month }\end{array}$ \\
\hline 3. & Format & $\begin{array}{l}\text { a. PDF \& VIDEO } \\
\text { b. PDF, VIDEO \& PPT }\end{array}$ \\
\hline 4. & Duration & $\begin{array}{l}\text { a. } 1 \mathrm{hr} \\
\text { b. } 2 \mathrm{hrs}\end{array}$ \\
\hline
\end{tabular}

\subsubsection{Experiment design}

Since the number of attributes and the number of attribute levels were small, full factorial design was chosen to achieve the best estimation of main effects. The profiles were directly presented to respondents; and the respondents were asked to express their strength of preference of each profile on an eleven-point scale (0-10) according to their preference, where 0 represented "I definitely wouldn't study online course" and 10 represented "I definitely would study online course". These profiles as part of the whole questionnaire could be found in the appendix. The basic model of conjoint analysis assumed a linear relationship between utility and each attribute level as follows:

$\mathrm{U}(\mathrm{X})=\sum_{i=1}^{m} \sum_{j=1}^{k} \alpha_{\mathrm{ij}} \mathrm{X}_{\mathrm{ij}}$

Where

$U(X)=$ overall utility of a profile

aij =the part-worth contribution or utility associated with the $\mathrm{j}^{\text {th }}$ level $(j=1,2, \ldots \mathrm{ki})$ of attribute

$x j j=1$ if the $j^{\text {th }}$ level of the $i^{\text {th }}$ attribute is present; $=0$ otherwise $k i=$ number of levels of attribute $i$

$\mathrm{m}=$ number of attributes

The importance of an attribute, $i$ is defined in terms of the range of the part-worths, aij, across the levels of that attribute.

The attribute's importance is calculated to determine its importance relative to other attributes, $W=\frac{I}{\sum_{i=1}^{m} I}$ so that $\sum_{i=1}^{m} W=1$

OLS regression technique was applied to estimate the preference functions of each respondent. Dependent variable was the profile rating, and independent variables were formed by the coded attribute levels. The estimated regression coefficients were then interpreted as the part-worth utilities that made up overall ratings of the profiles. The attribute's importance was understood as the extent to which each attribute contributed to the determination of the utility, i.e. to the overall preference. At last, total utility of every profile was computed and ranked from largest to smallest, assuming that the respondents were utility maximizers, who would select the profile that yielded highest utility.

\section{Results and Discussion}

From the results it was identified that most of the Agristudent's respondents are male and the non Agri sample respondents are female. It was observed that $8 \%$ of agricultural students were experienced in online courses, whereas only $74 \%$ of non agricultural students were experienced in online mode of distance education. The chi square analysis revealed that online experience of the agricultural and non agricultural students were statistically different.

\subsection{Preference of internet connectivity by the sample respondents}

Distance education is useful for those who are not able to attend the regular classes because of unavailability of time, long distance and job etc. Taking this into account, preference of internet connectivity by the respondents for doing online distance education was enquired and the results are presented in the Figure 1 and Figure 2.

From the Figure 1 , it could be concluded that $50 \%$ of agricultural students preferred to have the internet connectivity from home followed by library ( $25 \%$ ) and university $(18 \%)$. It could be seen from the Figure 2 that $46 \%$ of the non-agricultural students preferred to have internet connectivity from home followed by library (33\%) and university (17\%). This might be the reason that comfortability of the students to access 
Agricultural students

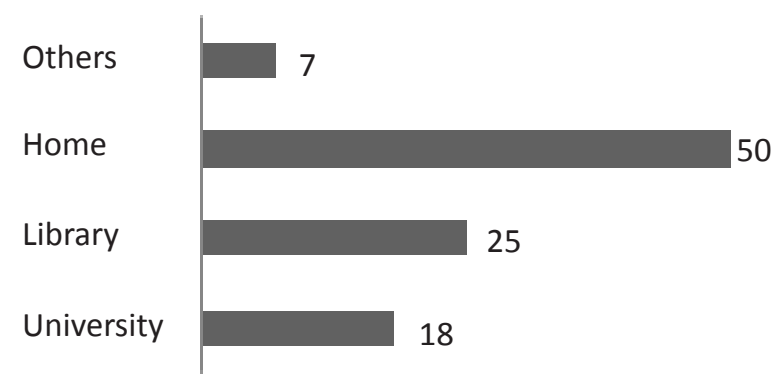

Figure 1: Preference of internet connectivity by agricultural students $(n=90)$

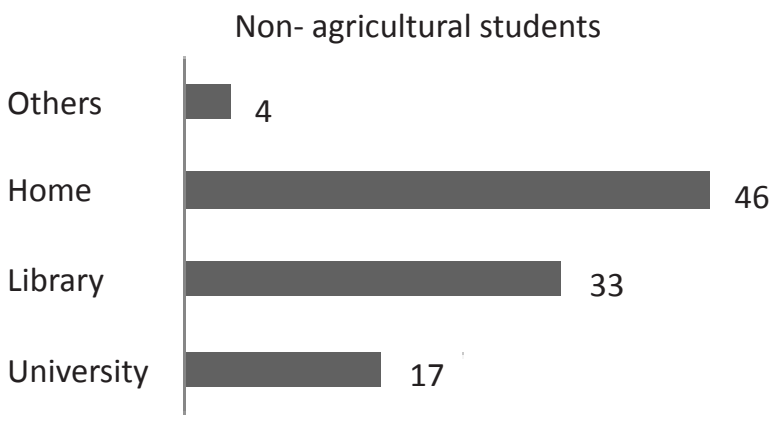

Figure 2: Preference of internet connectivity by non agricultural students $(n=90)$

the internet at any time to undergo the online courses. A meagre of the sample respondents preferred to have internet connectivity from other sources.

\subsubsection{Preference of the sample respondents in computer related task}

Preference of the sample respondents in computer related task was probed in order to understand the actual interest of the respondents in computer related task. The data collected on the preferences on the computer related tasks were analysed by calculating the mean score. The results are presented and discussed in the Table 2.

From the Table 2, it could be revealed that in case of agricultural students, using mail (4.0) and receiving documents electronically (3.6) were found to be most preferred task. Typing, accessing the web, sending documents, downloading documents, downloading multimedia material listening and viewing material were other preferred tasks in computer. In case of non-agricultural students, all tasks were neutrally preferred. The mean value for all the tasks was not less than 2.5. Hence, it could be inferred that both agricultural and non-agricultural students preferred to do the computer related tasks.

\subsubsection{Reasons for preferring online education}

To identify the reason for preferring online education, the sample respondents were asked to rank the following factors. The data collected were analysed and the results are given in the Table 3.
Table 2: Preference of the sample respondents in computer related task

\begin{tabular}{|c|c|c|c|}
\hline $\begin{array}{l}\text { SI. } \\
\text { No. }\end{array}$ & Computer related task & $\begin{array}{l}\text { Agricultur- } \\
\text { al student }\end{array}$ & $\begin{array}{c}\text { Non- } \\
\text { agricultural } \\
\text { student }\end{array}$ \\
\hline & & $\begin{array}{l}\text { Mean } \\
\text { score }\end{array}$ & Mean score \\
\hline 1. & Using email & 4.0 & 2.5 \\
\hline 2. & Typing & 2.6 & 2.5 \\
\hline 3. & Accessing the Web & 2.8 & 2.6 \\
\hline 4. & $\begin{array}{l}\text { Sending documents elec- } \\
\text { tronically }\end{array}$ & 2.8 & 2.6 \\
\hline 5. & $\begin{array}{l}\text { Receiving documents } \\
\text { electronically }\end{array}$ & 3.6 & 2.5 \\
\hline 6. & Downloading documents & 2.8 & 2.7 \\
\hline 7. & $\begin{array}{l}\text { Downloading multimedia } \\
\text { materials (audios and } \\
\text { videos) }\end{array}$ & 2.7 & 2.6 \\
\hline 8. & $\begin{array}{l}\text { Listening to audio on the } \\
\text { computer }\end{array}$ & 2.7 & 2.5 \\
\hline 9. & $\begin{array}{l}\text { Viewing video on the } \\
\text { computer }\end{array}$ & 2.7 & 2.6 \\
\hline
\end{tabular}

Source: Calculated from primary data

Table 3: Reasons for preferring online education $(n=180)$

\begin{tabular}{|c|c|c|c|c|c|}
\hline \multirow[t]{2}{*}{$\begin{array}{l}\text { Sl. } \\
\text { No. }\end{array}$} & \multirow[t]{2}{*}{ Reasons } & \multicolumn{2}{|c|}{$\begin{array}{l}\text { Agricultural } \\
\text { students }\end{array}$} & \multicolumn{2}{|c|}{$\begin{array}{c}\text { Non agricultural } \\
\text { students }\end{array}$} \\
\hline & & $\begin{array}{l}\text { Mean } \\
\text { score }\end{array}$ & Rank & $\begin{array}{l}\text { Mean } \\
\text { score }\end{array}$ & Rank \\
\hline 1. & $\begin{array}{l}\text { Flexibility of } \\
\text { study location }\end{array}$ & 52.49 & 1 & 54.32 & 1 \\
\hline 2. & $\begin{array}{l}\text { Flexibility of } \\
\text { study time }\end{array}$ & 52.32 & II & 50.73 & III \\
\hline 3. & $\begin{array}{l}\text { Less need to } \\
\text { go to campus }\end{array}$ & 51.93 & III & 51.36 & II \\
\hline 4. & $\begin{array}{l}\text { Limited face to } \\
\text { face interac- } \\
\text { tion }\end{array}$ & 50.28 & IV & 47.38 & VI \\
\hline 5. & $\begin{array}{l}\text { Online deliv- } \\
\text { ery methods }\end{array}$ & 48.93 & V & 48.82 & V \\
\hline 6. & $\begin{array}{l}\text { Spending time } \\
\text { on the com- } \\
\text { puter }\end{array}$ & 47.06 & VI & 47.09 & VII \\
\hline 7. & $\begin{array}{l}\text { Reliance on } \\
\text { my own self } \\
\text { discipline }\end{array}$ & 46.99 & VII & 50.30 & IV \\
\hline
\end{tabular}

Source: Calculated from primary data 
It could be concluded that among all the agricultural and non-agricultural respondents, flexibility of study location was the major reason for the students to prefer online education followed by flexibility of study time and less need to go to campus.

\subsection{Preference of respondents on the design of online mode of education}

The design of the online education is one of the important factors because it helps to determine convenience and preference of the respondents towards online program. Hence, the preference of the respondents towards the design of theonline program was studied. The results of the analysis including correlation coefficients, estimation of part-worth scores and relative importance of attributes are presented in the Table 4.

Table 4: Preference of respondents on the design of online mode of education $(n=180)$

\begin{tabular}{llccc}
\hline $\begin{array}{l}\text { SI. } \\
\text { No. }\end{array}$ & Dimensions & Particulars & $\begin{array}{c}\text { Utility } \\
\text { estimate }\end{array}$ & $\begin{array}{c}\text { Std. } \\
\text { error }\end{array}$ \\
\hline 1. & Course & Degree & -1.183 & .965 \\
& & Certificate & 1.183 & .965 \\
2. & Period & 6 months & -.639 & 1.286 \\
& & 3 months & .040 & 1.508 \\
& & 1 month & .599 & 1.508 \\
3. & Format & PDF \& video & 1.104 & .965 \\
& & PDF, video and PPT & -1.104 & .965 \\
4. & Duration & 1 hr & 3.675 & 1.929 \\
& & 2 hrs & 7.350 & 3.859 \\
& (Constant) & 3.147 & 3.067 & \\
& & Value & Sig. & \\
& Pearson's R & .634 & .005 & \\
Kendall's tau & .424 & .012 & \\
\hline
\end{tabular}

Source: Calculated from primary data

The correlation between the observed and estimated preferences person's R (0.63) and kendall's tau (0.42) indicated that there was reasonably higher agreement between the averaged profile rating and the predicted utility from the conjoint analysis. It could be concluded that the goodness-of-fit of the conjoint analysis is satisfactory.

Part worth utility was used to know the importance of each online program dimension attributes which intern provided information about the willingness of the sample respondents for studying online courses. It could be inferred from the results that with respect to duration the students preferred $2 \mathrm{hrs}$. (7.35) followed by $1 \mathrm{hr}$ (3.68). With respect to period, students preferred 1 month (0.60) followed by 3 month (0.04). With respect to course, students preferred certificate courses (1.18). The students did not prefer degree courses $(-1.18)$ to avail through online mode. With respect to format students preferred PDF \& Video (1.10).

\section{Conclusion}

Develop an exclusive websites for online courses in which the study materials should be easily accessible from any device including different types of smart phone and tablets. Along with the other means of online education like soft materials and pre recorded videos include more live interactive sessions with experts in the respective fields.

\section{Reference}

Abdulaziz, Y., Naser, A., 2014. E-learning in saudi arabia: a review of the literature. British Journal of Education, Society and Behavioural Science 4(5), 656-672.

Balamurugan, V., 2015. Learning experience of small farmers in sugarcane cultivation. Journal of Extension Education 27(1), 5376-5381.

Kumar, J., Suresh, A., Sundaramari, M., Puthira P.D., 2016. Understanding learning style variations among undergraduate students. Journal of Extension Education 28(4), 5727-5734.

Meera Shaik, N., Arun, K.S., Amtul, W., Vara, P.C., Muthuraman, P., Mangal, S., Viraktamath, B.C., 2010. E-learning in extension systems: empirical study in agricultural extension in india. Indian Journal of Extension Education 46(3), 94-101.

Raut, A.A., Sharma, G., 2009. Developing distance learning framework for promoting agriculture education. Indian Research Journal of Extension Education 9(3) 35-38.

Shashi, D., Seema, J., Chaturvedi, K.K., Bhardwaj, A., Goyal, R.C., Cini, V., 2012. An e-learning system for agricultural education. Indian Research Journal of Extension Education 12(3), 132-135.

Shaheen, A.S., 2017. Student teacher awareness of MOOCSmassive online open courses. International Journal of Educational Science and Research (IJESR) 7(6) 105-110.

Soujanya, S., Hiremath, Uma, S., 2013. Empowering rural women through distance education. Advance research Journal of Social science 4(1), 17-22.

Tamta, P., Ansari, A.M., 2015. University student's perception towards e-learning. International journal of extension education 6, 6-11.

Weichieh W.Y., Jenny W., Chunfu, C.L., 2013. Nursing students' evaluation of the effectiveness of online collaborative learning, British Journal of Education, Society and Behavioural Science 3(4) 382-394. 